\title{
Sacral neuromodulation outcomes in neurourological voiding dysfunction
}

\section{Resultados de la neuromulación sacra en la disfunción miccional neurológica}

Grisel Hernández-Martínez, ${ }^{1}$ Sandra Xochiquetzal Cruz-Ordóñez, ${ }^{2 \star}$

Paola Alejandra López-Hernández. ${ }^{2}$

Key words:

posterior sacral

neuromodulation,

neurourological

voiding dysfunction,

neurourological

diseases

Corresponding author:

*Sandra Xochiquetzal

Cruz Ordóñez. Hospital

Central Militar,

Boulevard Manuel

Ávila Camacho s/n,

Col. Lomas de Sotelo,

Av. Industria Militar y

General Juan Cabral,

Del. Miguel Hidalgo,

Ciudad de México,

C.P. 11200. Email:

sandraxo.cruz@gmail.

com

\section{Abstract}

Objective: To demonstrate the changes in the urodynamic parameters of patients with posterior sacral neuromodulation and compare these changes to their pre-implantation parameters.

Design: Observational, retrospective, comparative study of related variables. Urodynamic studies were performed on neurological patients who were candidates for posterior sacral neuromodulation $(n=9)$. The candidates for a definitive neuromodulator underwent comparative statistical analysis using student's t test for related samples. We evaluated on pressure-flow study: maximum flow, Pdet max, effectiveness of voiding, and compliance.

Results: Statistically significant results were found in the urodynamic measurements at peak flow $(\mathrm{Qmax} p<0.002)$ and in changes in detrusor pressures $(p<0.001)$, there were no statistically significant differences found in voiding effectiveness ( $\mathrm{p}=0.02$ ).

Limitations of the study-implication: A larger number of patients are needed to compare our results to international reports, and to adjust the time of implantation after neurological lesions, since our sample was very heterogeneous.

Originality: There are no reports of sacral neuromodulation in Mexican patients exclusively with neurological disorders as described in other populations; this sample is being described as the largest population of neuromodulator carriers with neurourological diseases in Mexico.

Conclusions: In spite of not finding differences in the effectiveness of voiding in our sample, this difference is of great clinical importance since it means a decrease in or suspension of clean intermittent catheterization, which is probably also reflected in the changes of the detrusor pressures that are within the limits and has benefits for the patient as protection of the upper urinary tract and a decrease of expenses.

Citation: Hernández-Martínez G., Cruz-Ordóñez S. X., López-Hernández P.A. Sacral neuromodulation outcomes in neurourological voiding dysfunction. Rev Mex Urol. 2022;81(6):pp. 1-8

${ }^{1}$ Secretaría de la Defensa Nacional, Hospital Central Militar, Ciudad de México, México.

${ }^{2}$ Secretaría de la Defensa Nacional, Escuela Militar de Graduados de Sanidad, Ciudad de México, México.

Received: September 30, 2021

Accepted: November 24, 2021

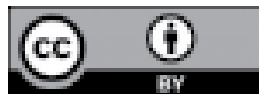




\section{Sacral neuromodulation outcomes in neurourological voiding dysfunction. Hernández-Martínez G., et al}

\section{Resumen}

Objetivo: Demostrar los cambios en parámetros urodinámicos de pacientes portadores de neuromodulador sacro posterior con respecto a sus parámetros previa implantación

Diseño: Estudio observacional, retrospectivo, comparativo (de variables relacionadas), se realizaron estudios urodinámicos a pacientes neurológicos candidatos a neuromodulación sacra posterior ( $n=9)$, a los candidatos a neuromodulador definitivo se realizaron análisis estadístico comparativo mediante $t$ de student muestras relacionadas evaluando en Flujo-presión: flujo máximo, Pdet max, efectividad de vaciamiento y complianza.

Resultados: se encontraron resultados estadísticamente significativos en mediciones urodinámicas de flujo máximo (Qmax $\mathrm{p}<0.002)$ y cambio en presiones del detrusor $(\mathrm{p}<0.001)$, no se encontraron diferencias estadísticamente significativas en efectividad de vaciamiento $(\mathrm{p}=0.02)$ Limitaciones del estudio-implicaciones: Hacen falta un mayor número de pacientes para comparar nuestros resultados con los reportes internacionales y ajustar el tiempo de implantación posterior a las lesiones neurológicas ya que nuestra muestra fue muy heterogénea

Originalidad: No se encuentran reportes de neuromodulación sacra en pacientes mexicanos con trastornos neurológicos exclusivos, como se han descrito en otras poblaciones; siendo esta la población descrita más grande portadora de neuromodulador con enfermedades neurourológicas descrita en México.

Palabras clave: Conclusiones: A pesar de no encontrar diferencias en la efectividad de vaciamiento en nuestra muestra, ésta diferencia es de suma importancia clínica ya que significa disminución o suspensión del cateterismo limpio intermitente, lo que probablemente se vea reflejado también por los cambios en las presiones del detrusor hacen que se encuentren dentro de los límites y tiene beneficios para el paciente como protección del tracto urinario superior y disminución de gastos.

\section{Introduction}

Lower Urinary tract dysfunction is a common condition, concomitant with previously diagnosed neurological patients. However, in some other conditions, a bladder-sphincter neuromuscular dysfunction can be present prior to the neurological presentation, and therefore, it hints to looking after a neurological concomitant disease (for example, neoplasms, root compression, myelodegenerative diseases, etc.). ${ }^{(1)}$ Unfortunately, the upper urinary tract has sometimes already suffered some damage at the time of the urological/neurourological 
diagnosis. This situation is of importance since it can lead to an upper function impairment, or a life-threatening condition.

Neurological diseases that affect the urinary tract and their urological manifestation regularly depend on the location of the neurological impact; for example, suprapontine, pons, upper motoneuron and lower spinal diseases (peripheral neuropathies), sacral disorders, demyelination disorders, and other syndromes without an evident neurological disorder. ${ }^{(1)}$

Any spinal injury, such as the ones secondary to car accident, weapon injuries, herniated discs, sudden hyperextension injuries, as well as non-traumatic causes, such as neurological infections, strokes, or even tumor, also present functional urological disorders. ${ }^{(2)}$ In fact, traumatic spinal injuries are some of the most frequent neurological diseases underlying urological functional diseases in our hospital, which is in line with the nature of a military hospital.

In 2016, the United States of America recorded an incidence of 12,000 spinal injuries, and $81 \%$ of these patients developed lower tract dysfunction within the first year post-injury. Until 1969, 75\% of spinal cord injury patients died because of neurological disease complications such as renal insufficiency and urosepsis. $^{(1)}$

Pelvic floor dysfunction, as well as genitourinary dysfunction, is a frequent consequence of spinal cord injury, and it usually brings a negative impact in the quality of life of patients, and a drop in life expectancy. ${ }^{(2)}$

In line with these neurological and urological correlation findings, previous research has developed a clinical classification based on urodynamic findings.
- Above brainstem: symptoms would include urinary frequency, urgency, with or without urge urinary incontinence. Bladder sensations can be normal or diminished. Urodynamics could show neurogenic detrusor overactivity, maybe with incomplete voiding, particulary in elderley patients

- Suprasacral spinal cord injuries: symptoms could include urinary frequency, urgency; with or without urge urinary incontinence, but it could be as severe as incomplete voiding; autonomic dysreflexia may be present when neurological injury is above $\mathrm{T} 6$, due to detrusor sphincter dyssynergia. Urodynamics may show neurological detrusor overactivity with detrusor sphincter dyssynergia and abnormal voiding.

- Sacral cord injury: symptoms include diminished bladder filling sensations and stress urinary incontinence. Urodynamic findings are underactive detrusor, and incomplete voiding with normo-active or underactive external urinary sphincter.

- Infra sacral injury: symptoms may include normal or diminished bladder filling sensations. Urodynamics may show underactive detrusor; external urinary sphincter may be hyperactive or with lack of relaxation. ${ }^{(2,3)}$

Bladder function is also dependent on the place of the injury; therefore, it is crucial to define this feature and prognosis to develop the correct long/short term urological approach. Sacral neuromodulation is an approved, secure, and efficient treatment in patients with lower urinary tract symptoms, when conservative measures aren't enough or fail; either those for detrusor overactivity or non-obstructive abnormal detrusor, or functional voiding. The success of proof lapse stimulation is defined as 
a reduction of $>50 \%$ in one or more micturition symptoms, in comparison with the initial symptoms. Then a definitive Implant Pulse Generator (IPG) is placed. ${ }^{(4)}$

Our hospital group previously evaluated outcomes of all posterior neuromodulation (SNM) implanted patients with encouraging results, improving urge urinary incontinence and post void residual rates in the general population. ${ }^{(5)}$ This is the reason why in this research we evaluated outcomes specifically for neurological voiding dysfunction, trying to contribute to the limited data in this kind of patients.

\section{Material and methods}

A retrospective, observational, comparative (related values) case series was performed from January 2010 to June 2021. We reviewed medical records of both, male and female patients, treated with posterior sacral neuromodulation due to dysfunctional voiding secondary to a neurological disease.
The inclusion criteria were as follows:

A) 18-year-old patients or older.

B) Signed informed consent by the patient for the use of their personal data for clinical research purposes.

C) Urodynamic study before and after neuromodulator placement.

D) Dysfunctional voiding related to a neurological disease.

E) Neurological disease must have been treated before neuromodulator placement in any of the implantation phases.

The exclusion criteria were:

a) An incomplete urodynamic report or charts, before or after neuromodulator placement.

b) Unable to follow up or contact.

c) Non neurological-related micturition dysfunction.

d) Untreated neurological condition.

e) Neurological condition evidenced after neuromodulator placement (Figure 1).

\section{Figure 1. Graphic example of inclusion and exclusion criteria}

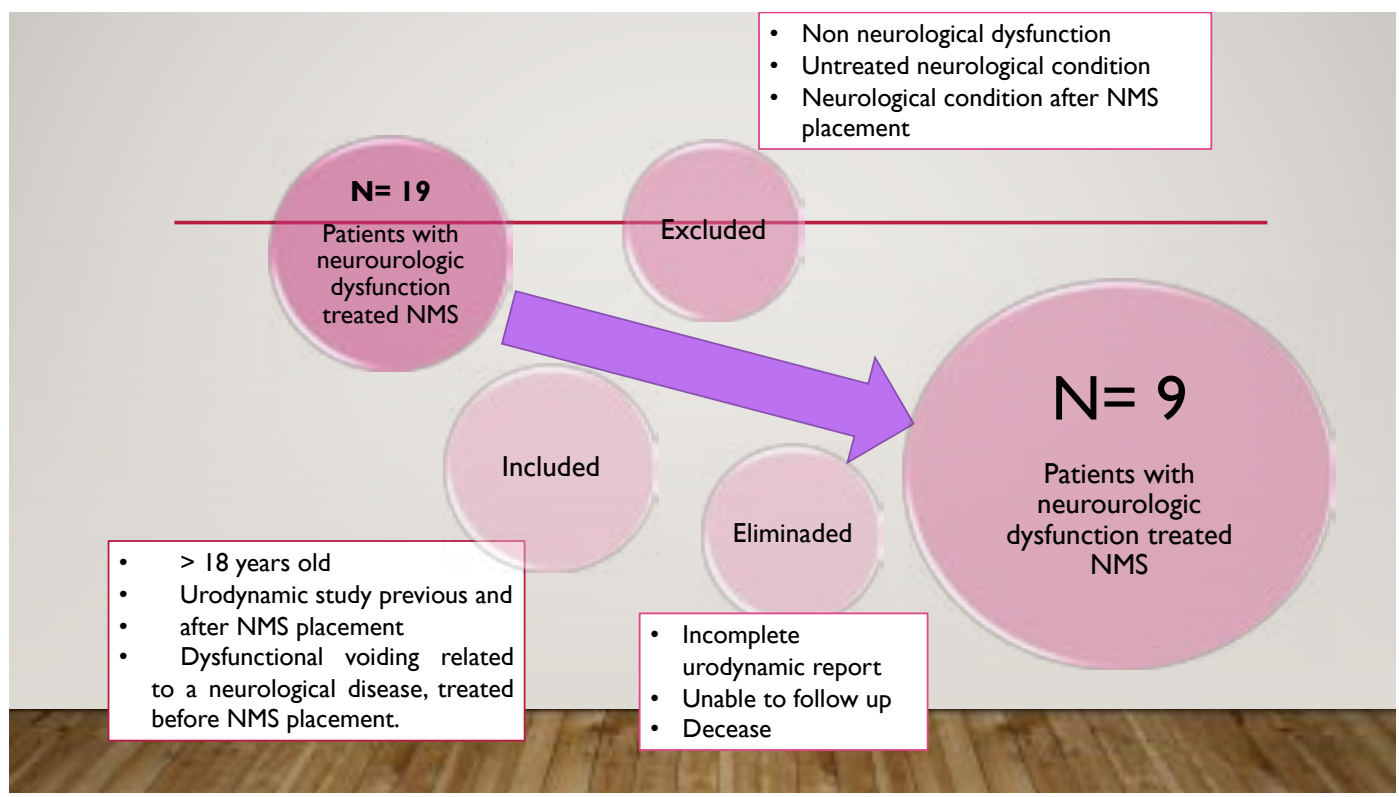


The analyzed variables were urinary incontinence per day if observed and number of clean intermittent catheterizations per day. The urodynamic variables were: voiding efficiency, maximum flow rate (Qmax), both at uroflow and pressure-flow studies, as well as maximum detrusor pressure (Pdet Max), and detrusor pressure at maximum flow rate (PdetQmax).

Our initial population (n) was 19 neurologically related dysfunctional voiding patients. However, 10 of them were lost due to different causes (see Results section); so, 9 patients were finally analyzed with the variables previously described.

As variables analyzed are continuous quantitative, distribution test was performed, as normal distribution was demonstrated, those variables underwent student's t test for related samples for statistical analysis to demonstrate differences before and after neuromodulator implantation.

Table 1. Demographic features

\begin{tabular}{|c|c|c|c|c|c|}
\hline ID & Age & Gender & Urodynamic diagnosis & Neurological diagnosis & $\begin{array}{l}\text { Injury } \\
\text { level }\end{array}$ \\
\hline 1 & 26 & M & DSD & $\begin{array}{l}\text { Pudendal nerve weapon injury } \\
\text { (unilateral) }\end{array}$ & S2 \\
\hline 2 & 40 & M & $\begin{array}{c}\text { Hiperactive sphincter, overactive } \\
\text { detrusor }\end{array}$ & $\begin{array}{c}\text { Radicular compression (lumbar } \\
\text { discal hernia) }\end{array}$ & L4, L5 \\
\hline 3 & 44 & $\mathrm{~F}$ & DSD & $\begin{array}{c}\text { Radicular compression (lumbar } \\
\text { discal hernia) }\end{array}$ & L3-L4 \\
\hline 4 & 57 & $\mathrm{~F}$ & Underactive detrusor & $\begin{array}{c}\text { Radicular compression (lumbar } \\
\text { discal hernia) }\end{array}$ & L5 \\
\hline 5 & 38 & M & DSD, Hiperactive sphincter & $\begin{array}{c}\text { Congenital sacral bone } \\
\text { malformation with radicular } \\
\text { compression }\end{array}$ & $\mathrm{S} 1-\mathrm{S} 3$ \\
\hline 6 & 20 & $\mathrm{~F}$ & $\begin{array}{l}\text { Overactive detrusor, DSD, urge } \\
\text { urinary incontinence }\end{array}$ & Myelomeningocele & L1-L5 \\
\hline 7 & 23 & $\mathrm{~F}$ & DSD & $\begin{array}{l}\text { Iatrogenic incomplete spinal } \\
\text { cord injury }\end{array}$ & L5 \\
\hline 8 & 47 & M & Underactive detrusor & $\begin{array}{c}\text { Radicular compression (lumbar } \\
\text { discal hernia) }\end{array}$ & L5-S1 \\
\hline 9 & 58 & M & Overactive detrusor, DSD & $\begin{array}{c}\text { Radicular compression (lumbar } \\
\text { discal hernia) }\end{array}$ & L5 \\
\hline
\end{tabular}

$\mathrm{M}=$ male, $\mathrm{F}=$ female, $\mathrm{DSD}=$ Dyssynergia sphincter-detrusor, 
We found heterogenous neurological presentations, the most frequent being radicular compression (lumbar discal hernia), in $55 \%$ of patients.

In order to assess surgical response, patients were classified by their urodynamic findings according to detrusor pressure in underactive or not: and they were also analyzed separately. We obviated post-void residual as a variable, but we did evaluate voiding efficiency (Table 2) and differences between compliance pre and post-surgery (Table 3). Main statistically significant differences were observed in PdetMax and PdetQmax $(p<0.001)$ with better outcome lowering detrusor pressures; elevating maximum flow and a discrete improvement in voiding efficiency; to evaluate changes in compliance we categorized this variable according to urodynamic diagnosis and found statistically significant differences in the over active detrusor/ detrusor sphincter dyssynergia group and no differences in the underactive detrusor group. Nevertheless, those discrete changes (not statistically significant) made two of three patients free of clean intermittent catheterization and have taken all patients to normal rates of post-void residual.

Table 2. Related sample variables (pre and postsurgical urodynamic measures)

\begin{tabular}{|c|c|c|c|c|c|c|c|c|}
\hline ID & $\begin{array}{c}\text { Qmax1 } \\
(\mathrm{ml} / \mathrm{seg})\end{array}$ & $\begin{array}{c}\text { Qmax2 } \\
(\mathrm{ml} / \mathrm{seg})\end{array}$ & $\begin{array}{l}\text { PdetMax1 } \\
(\mathrm{cmH} 2 \mathrm{O})\end{array}$ & $\begin{array}{l}\text { PdetMax2 } \\
(\mathrm{cmH} 2 \mathrm{O})\end{array}$ & $\begin{array}{c}\text { Pdet } \\
\text { Qmax1 } \\
(\mathrm{cmH} 2 \mathrm{O})\end{array}$ & $\begin{array}{c}\text { PdetQmax2 } \\
(\mathrm{cmH} 2 \mathrm{O})\end{array}$ & $\begin{array}{l}\text { VE1 } \\
(\%)\end{array}$ & $\begin{array}{l}\text { VE2 } \\
(\%)\end{array}$ \\
\hline 1 & 9 & 18 & 149 & 81 & 130 & 76 & 49 & 79 \\
\hline 2 & 3 & 9 & 120 & 75 & 125 & 70 & 64 & 81 \\
\hline 3 & 23 & 27 & 80 & 51 & 45 & 39 & 65 & 83 \\
\hline $4^{*}$ & 1 & 23 & 20 & 21 & 6 & 8 & 47 & 71 \\
\hline 5 & 16 & 20 & 71 & 45 & 42 & 42 & 51 & 78 \\
\hline 6 & 23 & 10 & 46 & 39 & 40 & 31 & 66 & 80 \\
\hline 7 & 8 & 12 & 22 & 30 & 13 & 28 & 59 & 86 \\
\hline $8^{*}$ & 5 & 21 & 18 & 26 & 20 & 24 & 61 & 85 \\
\hline 9 & 9 & 20 & 61 & 42 & 51 & 38 & 58 & 81 \\
\hline $\mathrm{p}$ & \multicolumn{2}{|c|}{0.002} & \multicolumn{2}{|c|}{$<0.001$} & \multicolumn{2}{|c|}{$<0.001$} & \multicolumn{2}{|c|}{0.023} \\
\hline
\end{tabular}

Qmax1= maximun flow before SNM; Qmax2= Maximum flow after SNM, PdetMax1=Maximum detrusor pressure before SNM; PdetMax2=Maximum detrusor pressure after SNM; PdetQmax1= detrusor pressure at maximum flow before SNM; PdetQmax2= detrusor pressure at maximum flow after SNM, VE1=Voiding efficiency before SNM; VE2= Voiding efficiency after SNM. All variables were analized by t student for related samples. *this subjects were diagnosed as underactive detrusor, so their difference was analized separately 
Table 3: Related variables (Compliance) stratified by urodynamic diagnosis (underactive detrusor or DSD and overactive detrusor)

\begin{tabular}{|l|c|c|c|}
\hline $\begin{array}{l}\text { UA/OA } \\
\text { or DSD }\end{array}$ & $\begin{array}{c}\text { Compliance } \\
\mathbf{1}\end{array}$ & $\begin{array}{c}\text { Compliance } \\
\mathbf{2}\end{array}$ & $\mathbf{p}=$ \\
\hline UA & 12 & 16 & \\
\hline UA & 15 & 21 & \multirow{2}{*}{0.05} \\
\hline DOIC & 10 & 11 & \\
\hline UA & 17 & 25 & \\
\hline DSD & 57 & 36 & \\
\hline OA & 64 & 39 & \\
\hline DED & 49 & 32 & 0.00 \\
\hline OA & 49 & 28 & \\
\hline DSD & 51 & 37 & \\
\hline
\end{tabular}

$U A=$ under active detrusor, $O A=$ overactive detrusor, $D E D=$ Dyssynergia sphincter-detrusor, DOIC $=$ Detru sor overactivity with impaired contractility

Parallel to these results, we also observed larger voiding volumes on the micturition chart.

\section{Conclusions}

The described results are encouraging, given the good responses in detrusor pressure, which may lead to protection of upper urinary tract, which, at the same time, is a common feature seen in neurological patients.

We evaluated urodynamic findings after neuromodulation procedures for research purposes, but in fact it is not an imperative praxis, as the follow-up of noninvasive parameters, such as a micturition diary, ultrasound and uroflowmetry are usually enough for a complete evaluation.

\section{Future Perspectives}

More long-term studies of larger numbers of patients are needed to make these findings replicable. As the primary center in which this surgery is performed in Mexico, we will continue assessing as many features as possible, in order to define which patients display better results, and are ideal for this treatment, looking for the maximal neurological benefit for patients.

\section{Acknowledgement}

To Dr. J. Gadú-Campos, our chief of Urology Department at Military Central Hospital in Mexico, for always encouraging research and continuous medical education and gender equality.

\section{Potential Conflicts of interest}

Dr. Grisel Hernández reports personal fees from Asofarma, Allergan, and Medtronic.

\section{Fundings}

This article has not been sponsored

\section{Bibliography}

1. Echavarría-Restrepo L G, Gallego- Mejía A, Gómez-Londoño M, Merino-Correa S M. Efectos de las lesiones del sistema nervioso sobre la fisiología de la micción. CES Medicina. 2019;33(3):182-91. doi: https://doi. org/10.21615/cesmedicina.33.3.3 


\section{Sacral neuromodulation outcomes in neurourological voiding dysfunction. Hernández-Martínez G., et al.}

2. Hamid R, Averbeck MA, Chiang H, Garcia A, Al Mousa RT, Oh SJ, et al. Epidemiology and pathophysiology of neurogenic bladder after spinal cord injury. World Journal of Urology. 2018;36(10):1517-27. doi: https://doi. org/10.1007/s00345-018-2301-z

3. Castro-Diaz D, Del Popolo G, Groen J, Hamid R. EAU Guidelines in Neuro-Urology. European Association of Urology; 2021.

4. Jairam R, Drossaerts J, Marcelissen T, van Koeveringe G, Vrijens D, van Kerrebroeck P. Predictive Factors in Sacral Neuromodulation: A Systematic Review. Urol Int. 2021 May 31;1-21. doi: https://doi.org/10.1159/000513937
5. Cervantes-Palma C, Campos-Salcedo JG, Mendoza-Álvarez LA, López-Silvestre JC, Díaz-Gómez C, Reyes-Equihua JL, et al. Evaluación de la eficacia, cambios en la calidad de vida y seguridad de la Neuromodulación sacra como tratamiento para pacientes con disfunción miccional en un Hospital de concentración de México. Rev Mex Urol. 2019;79(4):1-9.

6. Mass-Lindenbaum $\mathbf{M}$, Calderón-Pollak $\mathrm{D}$, Goldman HB, Pizarro-Berdichevsky J. Sacral neuromodulation - when and for who. Int Braz J Urol. 2021;47(3):647-56. doi: https://doi. org/10.1590/S1677-5538.IBJU.2021.99.08 